\title{
Structure and distribution of cold seep communities along the Peruvian active margin: relationship to geological and fluid patterns
}

\author{
K. Olu ${ }^{1, *}$, A. Duperret ${ }^{2}$, M. Sibuet ${ }^{1}$, J.-P. Foucher $^{3}$, A. Fiala-Médioni ${ }^{4}$ \\ ${ }^{1}$ Laboratoire Ecologie Abyssale, DRO/EP, IFREMER Centre de Brest, BP 70, F-29280 Plouzané, France \\ ${ }^{2}$ Département des Sciences de la Terre, UBO, 6 ave. Le Gorgeu, F-29287 Brest cédex, France \\ ${ }^{3}$ Laboratoire Environnements Sédimentaires, DRO/GM, IFREMER Centre de Brest, BP 70, F-29280 Plouzané, France \\ ${ }^{4}$ Université P. et M. Curie, Observatoire Océanologique de Banyuls, F-66650 Banyuls-sur-Mer, France
}

\begin{abstract}
Exploration of the northern Peruvian subduction zone with the French submersible 'Nautile' has revealed benthic communities dominated by new species of vesicomyid bivalves (Calyptogena spp. and Vesicomya sp.) sustained by methane-rich fluid expulsion all along the continental margin, between depths of 5140 and $2630 \mathrm{~m}$. Videoscopic studies of 25 dives ('Nautiperc' cruise 1991) allowed us to describe the distribution of these biological communities at different spatial scales. At large scale, the communities are associated with fluid expulsion along the major tectonic features (scarps, canyons) of the margin. At a smaller scale on the scarps, the distribution of the communities appears to be controlled by fluid expulsion along local fracturation features such as joints, faults and small-scale scars. Eight dives were made at one particular geological structure, the Middle Slope Scarp (the scar of a large debris avalanche) where numerous clam beds have been discovered. The spatial distribution of the chemosynthetic communities on this scarp indicates extensive fluid expulsion, but the low clam densities and low faunal diversity in clam beds and the presence of dead beds suggest fluid expulsion is temporally irregular. An exceptionally large clam field was observed at the bend of this scarp at the intersection of 2 faults. It extends for about $1000 \mathrm{~m}^{2}$ with the biomass of bivalves as high as $30 \mathrm{~kg} \mathrm{~m}^{-2}$ wet weight without shells. A strong and regular fluid flow, estimated at $400 \mathrm{~m} \mathrm{yr}^{-1}$, is required at this location to generate such a high chemosynthetic primary production. Temperature anomalies in the sediment were measured in situ in the main field and compared to clam density. The distribution of the bivalves at the metre scale is likely related to local variations in fluid flow and in fluid expulsion. patterns controlled by the nature of the subsurface sediment. Exceptionally large and densely distributed serpulids (Neovermilia n. sp.) were arranged in clumps of 20 to $30 \mathrm{~m}^{2}$, and covered $200 \mathrm{~m}^{2}$ of the field. Their abundance may be related to the filtration of chemoautotrophic free-living bacteria. Another 22 non-symbiotic species displaying various trophic strategies have been sampled or observed, and 5 are still undescribed new species. The resulting community structure is more complex than in other subduction systems described so far.
\end{abstract}

KEY WORDS: Cold seeps - Subduction zones - Peruvian margin Spatial distribution C Community structure

\section{INTRODUCTION}

The submersible exploration of some continental margins has revealed the occurrence of cold seep ecosystems in various geological settings. As in hydrothermal vent communities, cold seep communities are

•E-mail: kolu@ifremer.fr characterized by high biomass generated by chemosynthetic processes sustained by fluid expulsion. Given the universality and the high productivity of these ecosystems, they cannot be excluded from the energetic budgets of continental margins and hence are worth studying.

Cold seeps are found in passive and active margins. On passive margin settings, such as along the Gulf of Mexico, fluids are expelled in cold seeps by conduits 
provided by salt tectonic fracturation of the margin and salt diapirism (Bouma \& Roberts 1990, Kennicutt \& Brooks 1990). Fluids may also arise from brine sulfiderich seeps, as described for the Florida Escarpment, USA (Paull et al. 1984, Hecker 1985). Along the Louisiana Slope, USA, they are assumed to onginate from petroleum or natural gas seeps (Kennicutt et al. 1985, Rosman et al. 1987, MacDonald et al. 1989. 1990a, 1990b). Similar processes sustain communities on the continental slope off northern California, USA (Kennicutt et al. 1989). Finally, cold seeps found along the Laurentian Fan, Canada, may be linked to a slide assumed to have been triggered by an earthquake (Mayer et al. 1988)

On active margin settings, chemosynthetic communities have been observed along margins with a welldeveloped accretionary prism and along erosive margins. On accretionary prisms, communities are sustained by methane-rich fluids which are expelled by sediment compaction as described for the compressive margins off Oregon, USA (Suess et al. 1985, Kulm et al. 1986), for the Nankai Prism off Japan (Boulègue et al. 1985, Juniper \& Sibuet 1987, Le Pichon et al. 1987), for the Barbados Prism (Faugeres et al. 1990, Henry et al. 1990, Jollivet et al. 1990, K. Olu et al. unpubl.) and in Monterey Bay, southern California (Barry et al. 1994, Orange et al. 1994). In the Monterey Fan Valley system, which is developed at the base of the break-slope, sulfide-rich fluids also arise in the complex system of channeled valleys (Embley et al. 1990). Fluid emissions also occur at distensive active margins, as described for Sagami Bay, Japan (Okutani \& Egawa 1985, Sakai et al. 1987) and in subduction zones off Japan (Japanese and Kurile trenches), where fluid venting occurs along normal faults and largescale slides (Cadet et al. 1987, Sibuet et al. 1988).

In cold seep communities, dominant species are always large-size bivalves related to Mytilidae (Kennicutt et al. 1985, MacDonald et al. 1989, 1990a, 1990b, Jollivet et al. 1990) or Vesicomyidae (Suess et al. 1985, Laubier et al. 1986, Rosman et al. 1987, Hashimoto et al. 1988, Jollivet et al. 1990, Olu et al. unpubl.). These species rely on sulfide or methane oxidation via chemoautotrophic endosymbiotic bacteria (Kulm et al. 1986, Brooks et al. 1987, Fiala-Médioni \& Le Pennec 1988, Cary et al. 1989, Saino \& Ohta 1989). Although high bivalve densities and biomasses have been reported (Ohta \& Laubier 1987, Hashimoto et al. 1989, MacDonald et al. 1990a), bivalve populations are generally concentrated in small beds or discontinuous areas. On other species in these communities, some species may be found associated only with seeps, whereas other may be found nearby and are attracted by the local. organic enrichment. This 'accompanying' fauna is often dominated by suspension and deposit feeders
(Juniper \& Sibuet 1987, Rosman et al. 1987, Jollivet et al. 1990), and except in the shallower Gulf of Mexico hydrocarbon seeps (MacDonald et al. 1989, Camey 1994), there are few carnivores. Except in these relatively shallow seeps, biological diversity seems to be low in the cold seep communities reported up to now.

Cold seep communities were discovered along a distensive and erosive margin off northern Peru during the 'Nautiperc' cruise in 1991 (Fiala-Médioni et al. 1992). The broad exploration of the continental slope allows us to describe in this paper the spatial distribution and taxonomic composition of chemosynthetic communities over a large bathymetric range. A multidisciplinary approach including in situ measurements was used in an attempt to unfold the relationship between tectonic and sedimentary features, fluid expulsion and biological patterns at several spatial scales. Estimates are made of the area covered and the density and biomass of bivalves in a large clam field on the margin. The non-symbiotic species and their trophic strategies are described in order to compare the diversity and complexity of the several communities observed along the margin, and with cold seep communities described elsewhere.

\section{MATERIALS AND METHODS}

Studied area and main geological features. The northern Peruvian margin is characterized by a steep slope, normal faulting and large-scale instabilities (Bourgois et al. 1986, Duperret et al. 1995). It is therefore considered as an extensional active margin, with massive subsidence and lack of well-developed accretionary prism, according to the definition proposed by Aubouin et al. (1984). In situ exploration was conducted along the Paita area of this margin with the French submersible 'Nautile'. This part of the northern Peruvian margin is located between 5 and $6^{\circ} \mathrm{S}$ and between 80 and $82^{\circ} \mathrm{W}$, and extends $40 \mathrm{~km}$ from the upper slope to the subduction contact (Fig. 1). The continental slope consists of 3 main domains separated by prominent tectonic features (Fig. 2). The upper slope extends from a depth of 200 to $3400 \mathrm{~m}$ and is incised by deep parallel canyons trending east-west that cut a detachment fault, referred to as the Upper Slope Scarp or USS (Lagabrielle et al. 1992, Bourgois et al. 1993). The middle slope is between 3400 and $4000 \mathrm{~m}$ deep and is characterized by a large curved scarp, oriented east-west in the northern part and north-south in the southern part. This scarp is called the Middle Slope Scarp or MSS (Lagabrielle et al. 1992, Bourgois et al. 1993) and represents the head-scar track of a large-scale debris avalanche. Finally, the lower slope extends from 4000 to $5600 \mathrm{~m}$ and shows a chaotic topography indicative of 


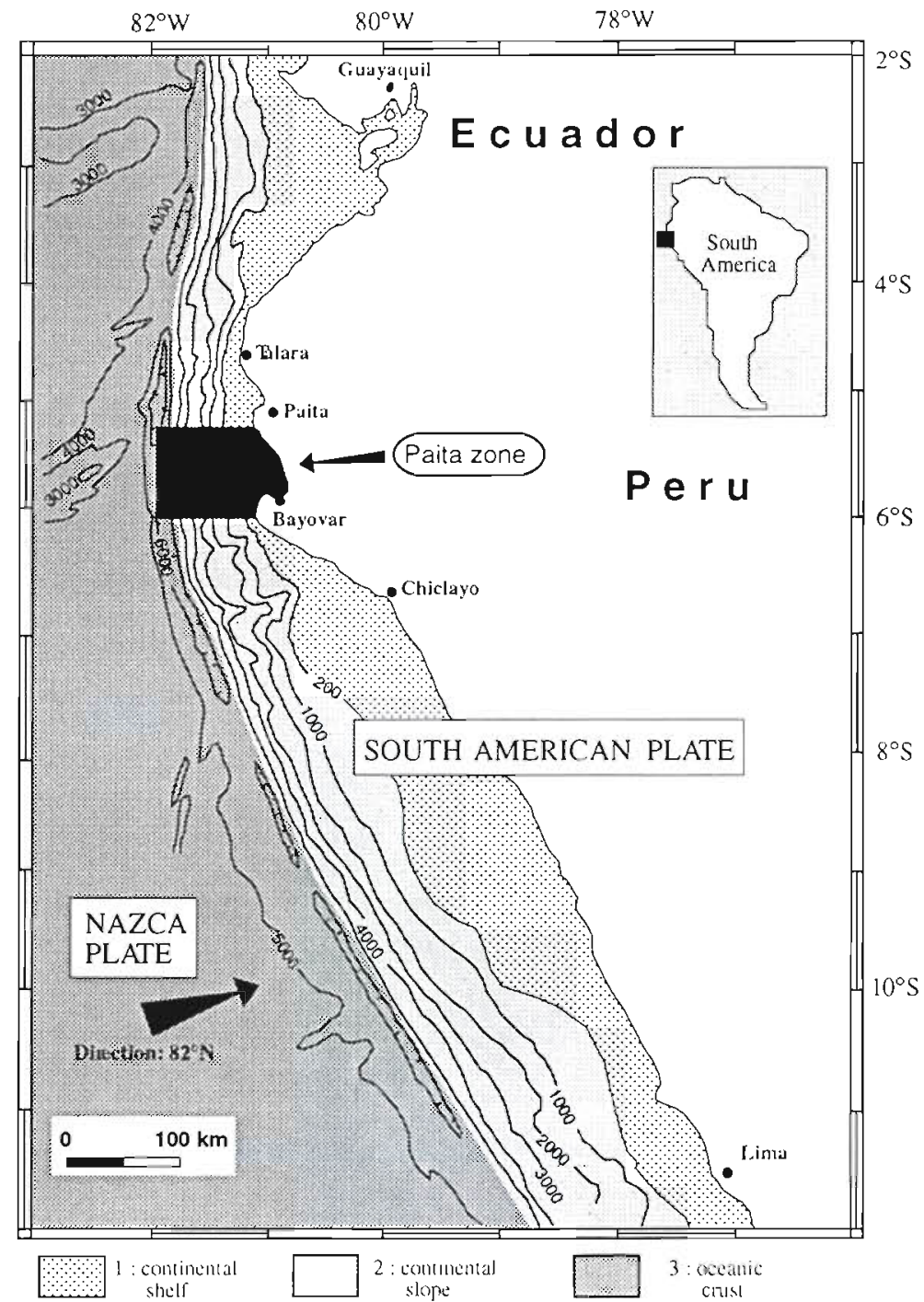

Fig. 1. Simplified bathymetry along the northern Peruvian margin. Isobaths every $1000 \mathrm{~m}$. Black arrow: direction of convergence between Nazca plate and South American plate. Black area: location of the area prospected by submersible during the 'Nautiperc' cruise offshore from the Paita area (adapted from Duperret et al. 1995)

a debris avalanche deposit. The edge of the margin is marked by a rectilinear scarp, called the Trench Scarp, or TS (Duperret et al. 1995) which extends from $5380 \mathrm{~m}$ to $4670 \mathrm{~m}$. Dives conducted along this scarp have shown that its lower part is gently sloping and embedded in a thin sediment cover and that its upper part is steeper with high and visible fracturation.

Twenty-five dives were conducted along the scarps of the Paita area (Fig. 3), where active seepage was most likely. Six dives explored the TS (4600 to $5400 \mathrm{~m}$ ), 16 dives the MSS ( 3400 to $4000 \mathrm{~m}$ ), including 8 on the largest active field discovered around $3550 \mathrm{~m}$, and 3 dives explored the canyons of the USS between 2800 and $2300 \mathrm{~m}$.
Strategy of the study. The spatial distribution of bivalve communities in relation to geological structures was recorded by video. Recordings were made at 3 spatial scales: (1) Along the margin, recordings were made of communities dominated by different species of Vesicomyidae that were several kilometers apart. (2) Along the MSS, and especially at the bend of this head-scar track where clam beds are numerous, observations were made at a scale of $100 \mathrm{~m}$. (3) In the largest active clam field of the area, or Main Active Field (MAF) at the bend of the MSS, the microdistribution and density of clams and the biological diversity were described at the metre scale.

Analytical methods. Bathymetric and microbathymetric maps were drawn using information from the submersible navigation system of the dive tracks and depth. Moreover, geological and biological videoscopic observations were used to prepare the 1:500 scale map (isobaths placed $10 \mathrm{~m}$ apart) of the MAF. As the acoustic navigation was poor at this scale, the dives were cross-checked using videoscopic observation of some identified faunal clumps and morphological features. Microcartography of the field was made from estimates of the area covered by video at each frame and from the submersible course that was recorded on the video frame. The surface area covered by video was estimated using geometrical calculations based on the altitude of the submersible and the focal length of the camera, as proposed by Jollivet (1993). Megafauna was identified both from samples and photographs (Fig. 4). Live bivalves are recognized by their siphons protruding from the sediment whereas dead clams are recognized by shells lying at the sediment surface. Clam clusters were classified into categories with mean clam densities of $0,1,10,50$, $100,250,500$ or 1000 ind. $\mathrm{m}^{-2}$, or into an additional category of clam clusters with 45 ind. $\mathrm{m}^{-2}$ in clumps of polychaete serpulids. Because the distribution of bivalves was sometimes patchy, the percentage area of clam clusters in a $10 \mathrm{~m}^{2}$ sampling surface was estimated. Mean density in a $10 \mathrm{~m}^{2}$ surface was estimated from the percentage cover of clusters in a $10 \mathrm{~m}^{2}$ surface and the clam density within a cluster. The mean clam density in the MAF was estimated considering the percentage cover of each density category in the total field (Table 1). Wet weights without shells were made on 


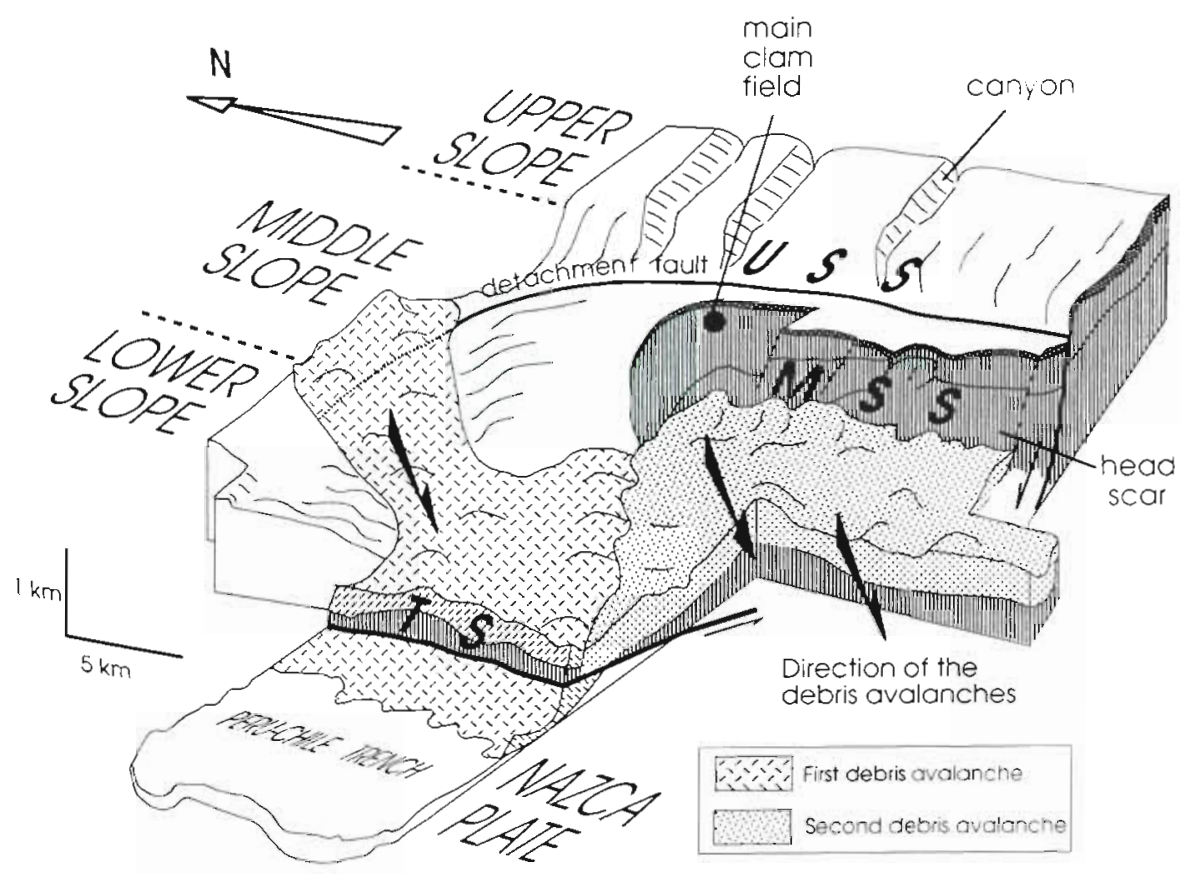

Fig. 2. Three-dimensional diagram showing the main geologic and tectonic features identified in the Paita area. USS: Upper Slope Scarp; MSS: Middle Slope Scarp; TS: Trench Scarp. Main Active Field (MAF) is located at the scar of the debris avalanche (adapted from Duperret et al. 1995)

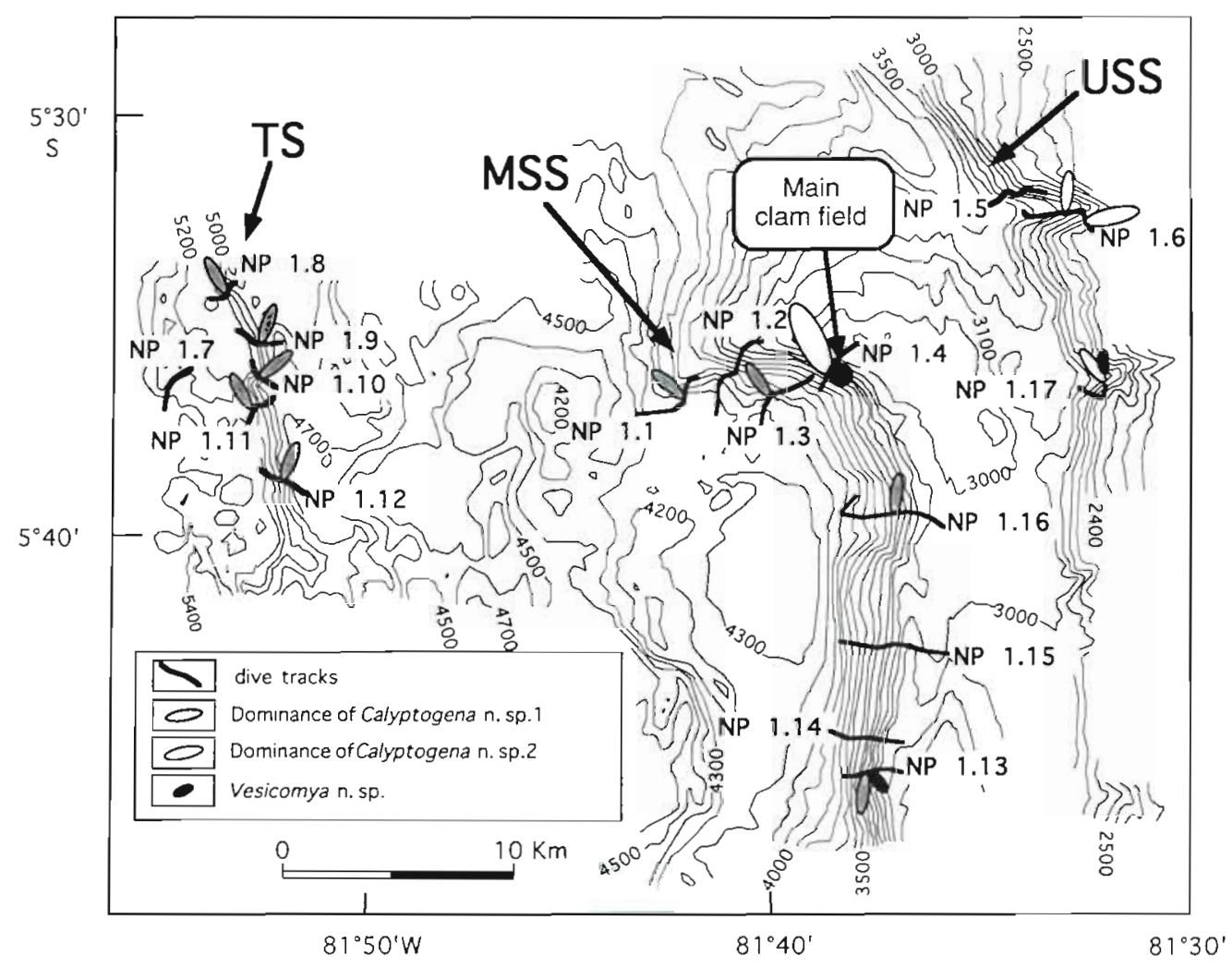

Fig. 3. Dive tracks and location of vesicomyid bivalves in the Patta area along the 3 scarps (USS, MSS, TS). Size of symbols for bivalve beds is proportional to size of clam field. Largest symbol corresponds to the main clam field studied (MAF) 
Table 1. Mean clam densities and areas covered by clam clusters. Mean densities on the $10 \mathrm{~m}^{2}$ sampling surfaces are estimated using densities in the clusters and percentage of the $10 \mathrm{~m}^{2}$ areas covered by these clusters. Mean clam density of the field $\left(39.5\right.$ ind $\mathrm{m}^{-2}$ ) is estimated considering mean densities on the $10 \mathrm{~m}^{2}$ surfaces and percentage of total field area covered by each class

\begin{tabular}{|cccc|}
\hline $\begin{array}{c}\text { Clam density } \\
\text { in the clusters } \\
\text { (ind. } \mathrm{m}^{-2} \text { ) }\end{array}$ & $\begin{array}{c}\% \text { covered by } \\
\text { the clusters on a } \\
10 \mathrm{~m}^{2} \text { surface }\end{array}$ & $\begin{array}{c}\text { Mean density on } \\
\text { a } 10 \mathrm{~m}^{2} \text { surface } \\
\text { (ind. } \mathrm{m}^{-2} \text { ) }\end{array}$ & $\begin{array}{c}\% \text { of } \\
\text { total area }\end{array}$ \\
\hline 0 & 0 & 0 & 5 \\
1 & 100 & 1 & 10 \\
10 & 100 & 10 & 22 \\
50 & 100 & 50 & 11 \\
100 & 10 & 10 & 13 \\
250 & 12.5 & 31.25 & 15 \\
500 & 10 & 50 & 3.5 \\
1000 & 50 & 500 & 4.5 \\
$45^{\text {a }}$ & 20 & 9 & 16 \\
${ }^{a}$ Calyptogena n. sp. 2 living among Serpulidae & \\
\hline
\end{tabular}

9 clams fixed in formalin, with a $20 \%$ correction, as suggested by Mills et al. (1982). A rough estimate of total bivalve biomass in the MAF was calculated from size and weight measurements of collected clams.

In situ measurements of bottom seawater and pore water temperatures at 3 or 4 different depths in the upper $50 \mathrm{~cm}$ of sediment were taken in the MAF at 8 distinct stations that differed in microdistribution of clams and in sedimentary patterns. Temperature measurements were made from the submersible with the IFREMER (Brest, France) 'T-Naut' temperature probe. To determine temperature anomalies in sediments of the MAF, one reference measurement was taken outside of the MAF, in an area assumed to be not affected by fluid seepage. The excess temperature is calculated from the temperature difference at $0.4 \mathrm{~m}$ depth below the seafloor. A temperature gradient $\left({ }^{\circ} \mathrm{C} \mathrm{m}^{-1}\right)$ was calculated at each station from the temperature at the sediment surface and at the deepest measurement in the sediment.

\section{RESULTS}

\section{Spatial distribution of communities along the Paita area}

Chemosynthesis-based communities dominated by 3 species of Vesicomyidae were observed along the 3 scarps from the upper slope $(2630 \mathrm{~m})$ to the subduction contact $(5140 \mathrm{~m})$. Boulègue et al. (1992) proposed that these species utilize reducing elements provided by fluids, via symbiosis with chemosynthetic sulfuroxidizing bacteria. Ultrastructural analysis of the gill tissues of the 3 species reveals endocellular bacteria able to incorporate and oxidize sulfur elements (A. Fiala-Médioni unpubl. data). According to their morphological characteristics (B. Métivier pers. comm.), 2 species belong to the genus Calyptogena and the third, less abundant species, belongs to the genus Vesicomya. These generic names are provisional, however, because Calyptogena and Vesicomya are considered to be cryptic species (Vrijenhoek et al. 1994). Both species of Calyptogena, which dominate these communities, are new to science (B. Métivier pers. comm.). Calyptogena n. $\mathrm{sp} .1$ is elongate (Fig. 5A) and forms clusters of 10 to 100 large individuals (up to $20 \mathrm{~cm}$ ) (Fig. 5B). Calyptogena n, sp. 2 is more rounded (Fig. 5C) and is generally smaller than Calyptogena n. sp. 1. Calyptogena n. sp. 2 is found in various size clusters and is the dominant species in the MAF, with abundances of several thousands of clams over whole clam field area (Fig. 5D). The 2 species of Calyptogena show different spatial distribution and bathymetric ranges (Fig. 3).

\section{Trench Scarp communities}

Calyptogena n. sp. 1 communities were observed between 4795 and $5137 \mathrm{~m}$ along the TS, and this is the only species observed in the deepest part of the margin (Fig. 3). Clam beds are found mostly along the widely fractured bare cliffs of this part of the slope. Only a few low-density clam beds including a few individuals are present in the gentle parts of the slope which are covered by thick mud.

\section{Middle Slope Scarp communities}

Numerous communities have been observed along this widely explored scarp. Calyptogena n. sp. 1 communities settle in the deepest part of the scarp (3600 to $4000 \mathrm{~m}$ ) and are sometimes associated with Vesicomya n. sp. Communities dominated by Calyptogena n. sp. 2 live between 3400 and $3560 \mathrm{~m}$. Few individuals of Calyptogena n. sp. 1 occur in these communities, however. Clam beds are particularly numerous at the bend of the scarp (Fig. 6A), where the north-south and eastwest trending structures intersect (Duperret et al. 1993). These beds extend over a wide area, between 3500 and $3560 \mathrm{~m}$. They are located along fractures, joints and on little scars with fresh screes (Fig. 6B). The clusters are small in size and show low clam densities. Some beds are composed entirely of dead clams. The largest active clam field, the MAF, is located on a step 


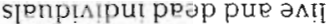
usinfunstp of posn st suoudis upj jo aวuasaid ( - numoว z ds 'u puabold e UI ('ds sndopวoypuag) sndopo

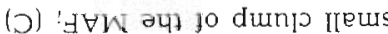
e woIf ds PIILIJANOZN SUIOM p!jndias to 6umpalloo (g) ! $\exists \forall W$

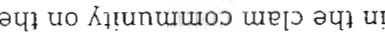

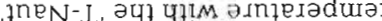
to juauaInseaw $(\forall)$.
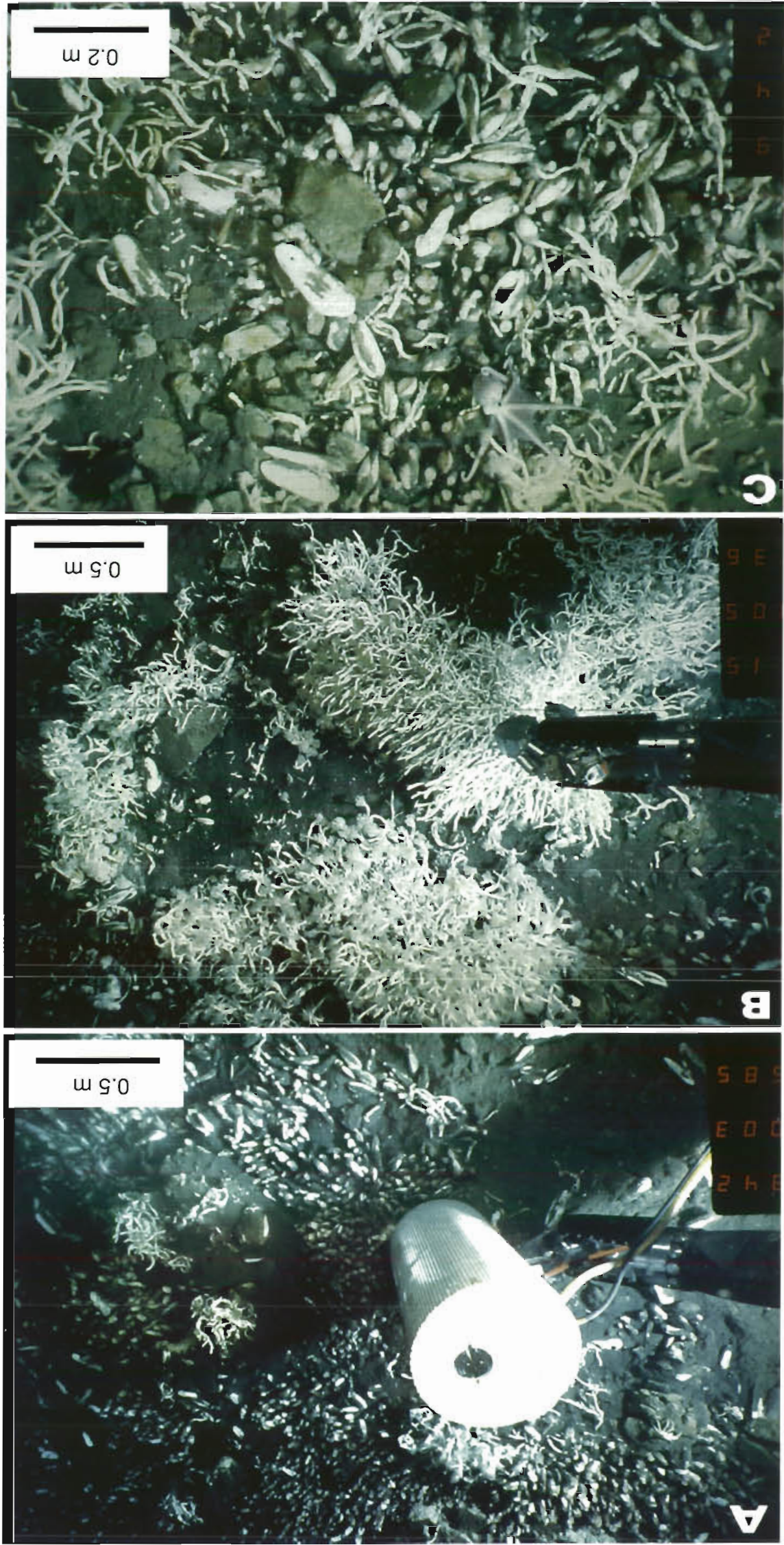

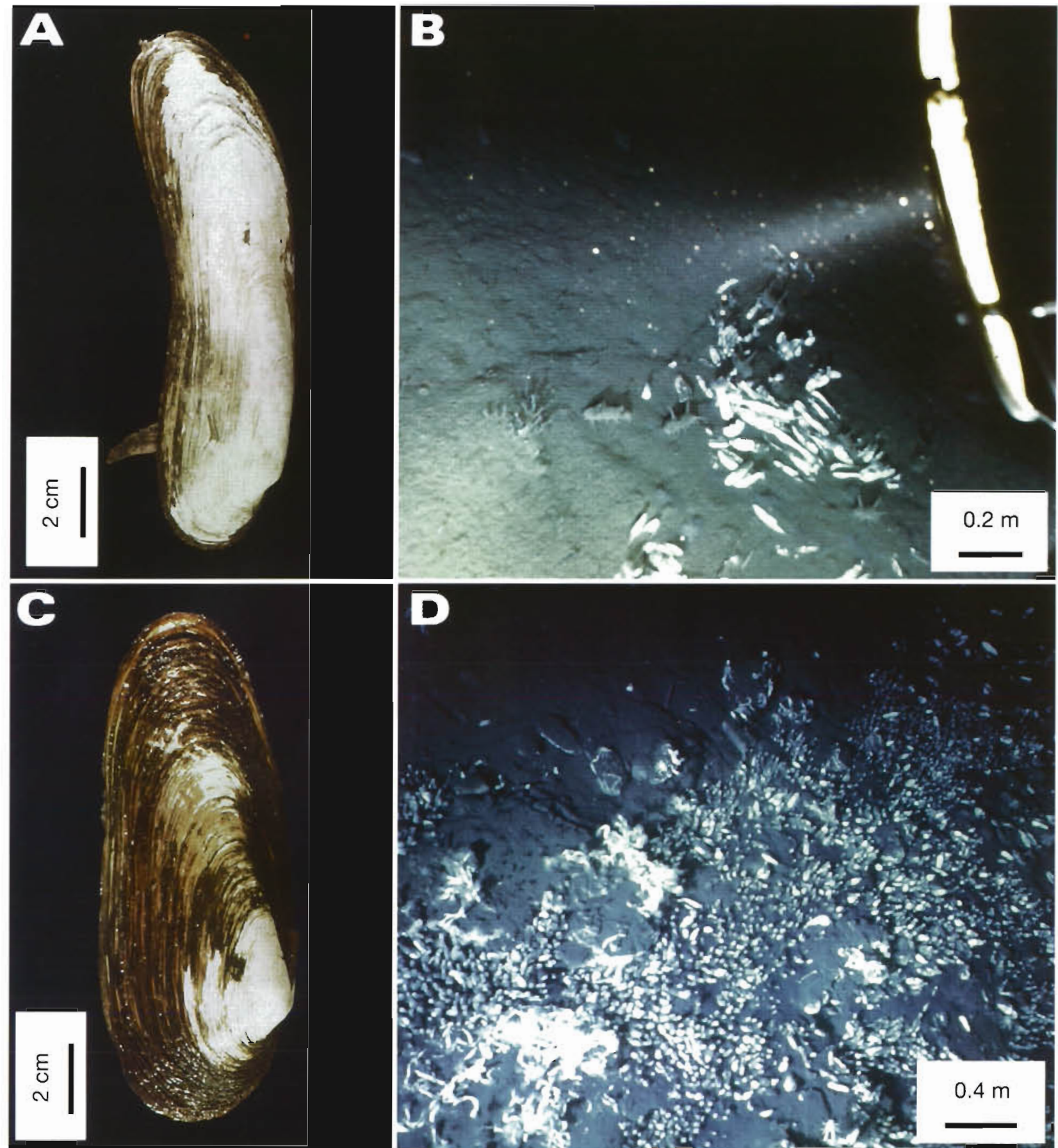

Fig. 5. (A) Calyptogena n. sp. 1; (B) community dominated by Calyptogena n. sp.1, along the TS, 4170 m. Some individuals are dead, lying on the sediment; live individuals are buried with siphons exposed. Holothurians belong to the genus $S c o t o p l a n e s$ (C) Calyptogena n. sp. 2; (D) community dominated by Calyptogena n. sp. 2 within the MAF at the bend of the MSS, $3520 \mathrm{~m}$. Note the high density in the clusters. Only the siphons are visible. Some small serpulid thickets Neovermilia n. $5 \mathrm{p}$. are attached on rocks. Numerous galatheids Munidopsis crassa are in the clam clusters

of the scarp covered by debris and is located at the intersection of an east-west fault system, composed of a cliff that represents the southern part of a spur, and a scarp, turned eastward. This field contains several thousand clams and large serpulid clumps.
Upper slope communities

Living along the canyons of the upper slope between 2630 and $3100 \mathrm{~m}$ are Calyptogena n. sp. 2 and sometimes Vesicomya n. sp. Clam beds of 50 to 100 indi- 

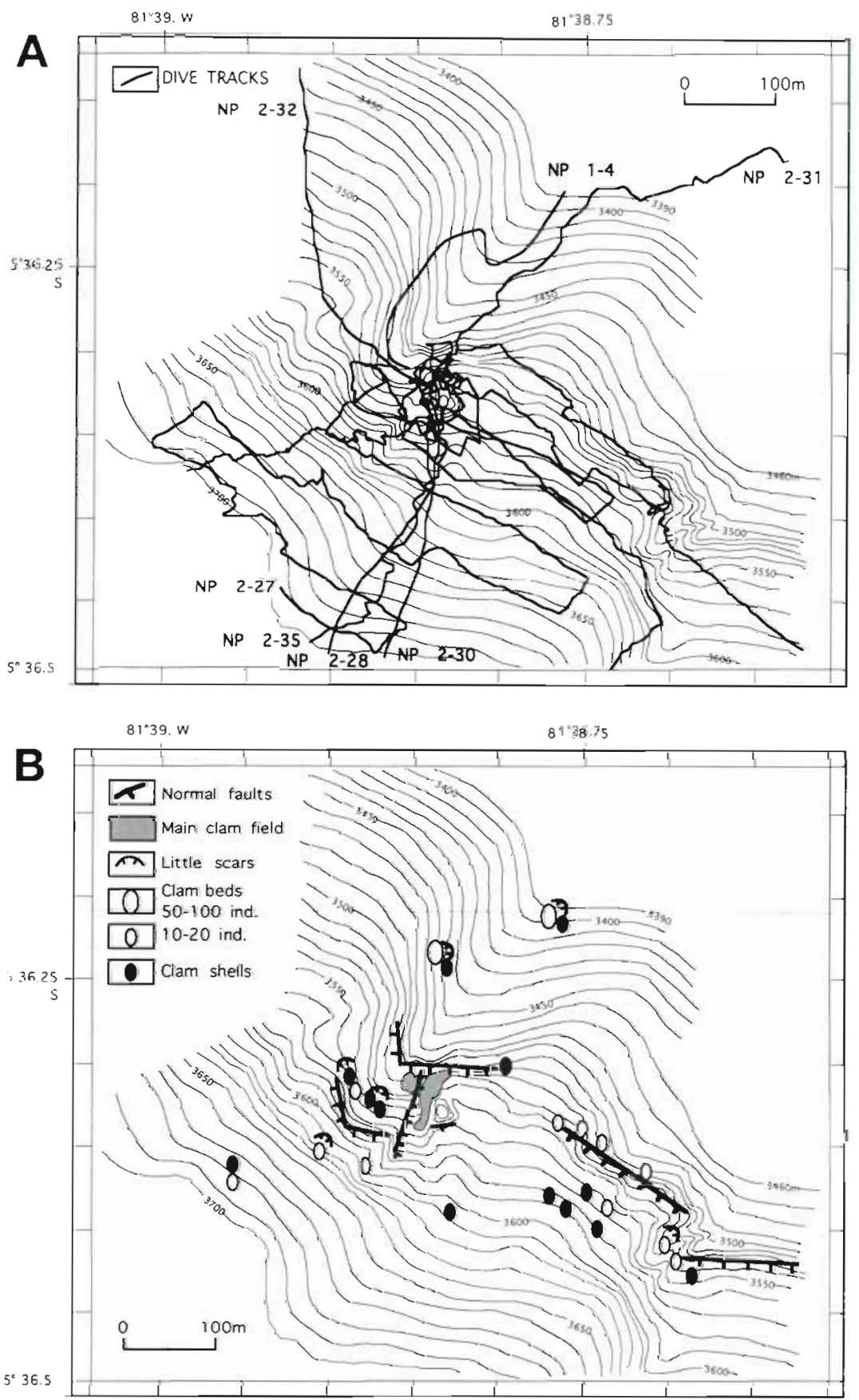

Fig. 6. (A) Dive tracks along the bend of the MSS. A large portion of the scarp and the MAF located in the center of the area were explored in 7 dives. (B) Distribution of live and dead Calyptogena n. sp.1 beds in relation with tectonic features. Live clam beds appear to be associated with faults and scars

\section{Detailed description of the main active field (MAF) and in situ experiment}

The MAF of the Paita area is the largest clam field described so far on continental margins. The total surface area is about $1000 \mathrm{~m}^{2}$ (Fig. $7 \mathrm{~A}$ ) and is covered by Calyptogena n. $\mathrm{sp}, 2$ in spatially heterogeneous patches, and by large serpulid thickets of the genus Neovermilia ( $\mathrm{H}$. Zibrowius pers. comm.). A few live or dead Calyptogena n. sp. 1 occur in some places. Some shells of a protobranch bivalve of the family Solemyidae, which lives buried in the sediment, are present in the lower part of the field. Several other taxa were observed and will be described later.

Bivalve microdistribution

The major part of the MAF is characterized by small-size debris and little mud cover (Fig. 7A). Most of the clams live on this facies. The highest densities of bivalves (up to 1000 ind. $\mathrm{m}^{-2}$ ) were found at the base of the fault, in the area of steepest slope. The occurrence of small-size clams may indicate that recruitment recently occurred in some of these beds. In this area, fluids seem to escape under flat slices of mudstone, on which barite deposits linked to fluid expulsion were sampled. At the boundaries of this area, clam and serpulid abundances decrease rapidly. In the upper part of the field, the lower part of the east-west scarp is formed by larger screes and bare rocks that are colonized by small serpulid thickets and are devoid of clams. The eastern part of the field is bound by a muddy area, entirely devoid of fluid-related fauna. Mud also covers the debris in the lower part of the field where clam densities are low (1 to 10 ind $\mathrm{m}^{-2}$ ), small-size clams are absent and a large percentage of clams in the clusters are dead.

Clam densities are highly variable in the MAF (Table 1). The field contains areas uniformly covered by clams with relatively low densities ( 1 to 50 ind. $\mathrm{m}^{-2}$ ), including clams living among serpulids (last category), whereas other areas have dense clusters of 250 to viduals in relatively high-density clusters were observed exclusively along the upper parts of the canyon walls that showed outcrops with faulting. The deeper parts of the canyons are buried in a thick sediment cover and are devoid of cold seep species. 


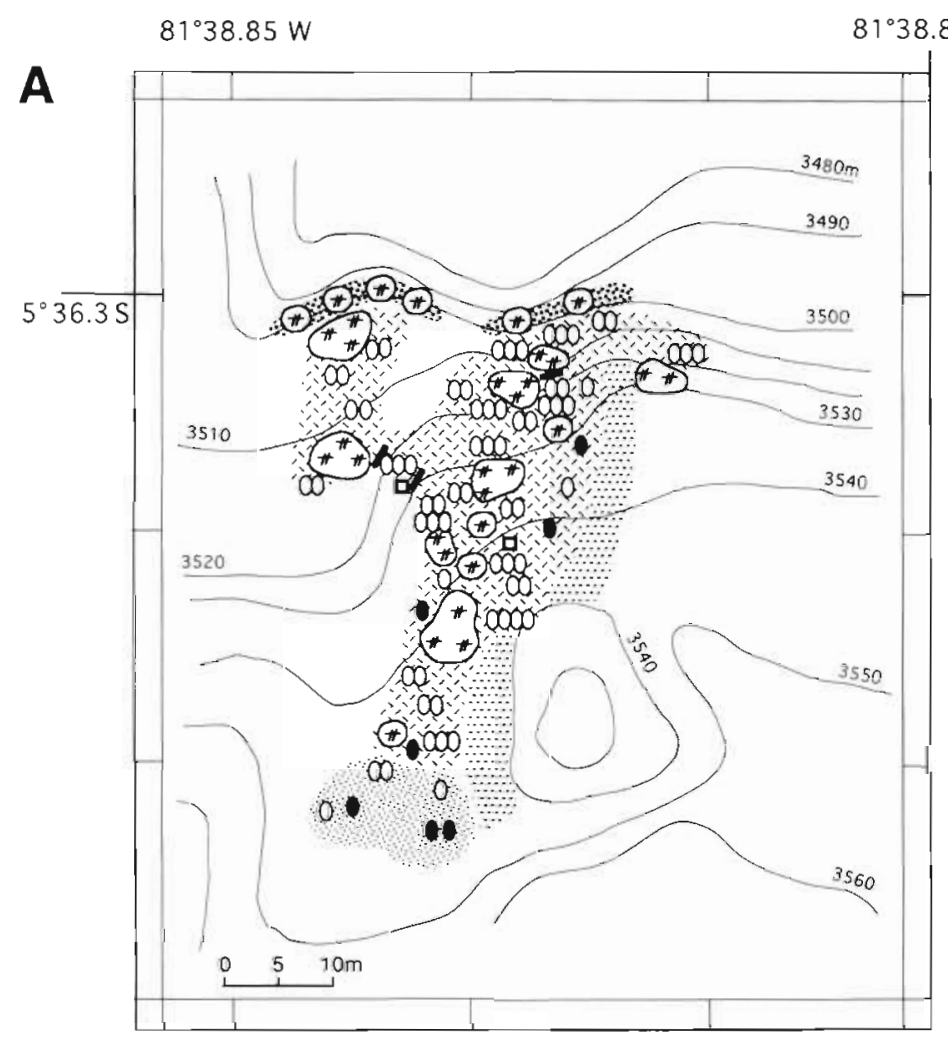

Sedimentary facies

3.X? Bare rocks

식 Debris with little

pelagic mud

10 Debris with

pelagic mud

Pelagic mud

Clam densities (ind. $\mathrm{m}^{-2}$ )

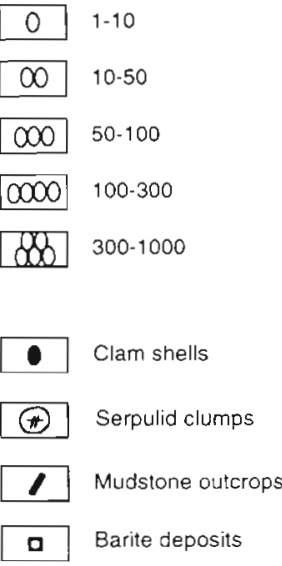

Fig. 7. (A) Microdistribution of clam clusters and serpulid clumps in the MAF in relation to sedimentary facies. (B) Location of temperature measurements and bivalve sampling in the MAF

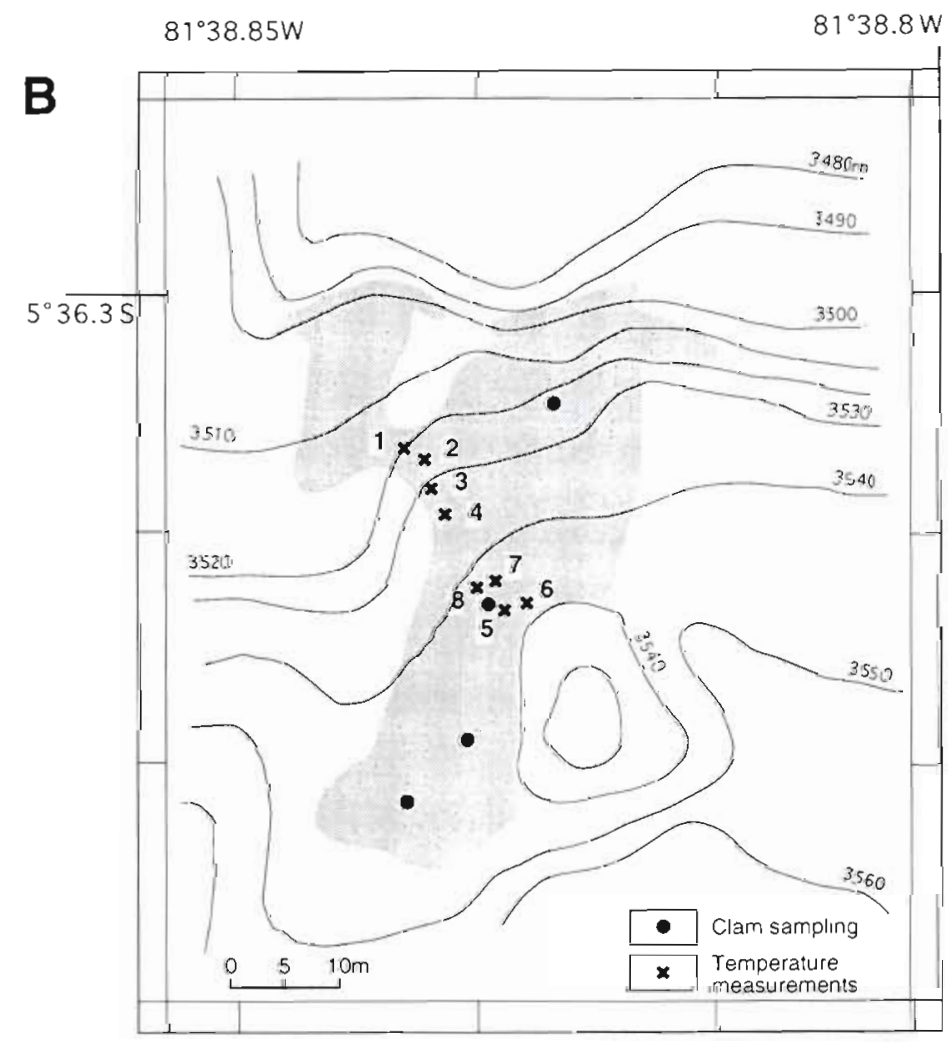

1000 ind. $\mathrm{m}^{-2}$ in dispersed patches (coverage is 10 to $50 \%$ of a $10 \mathrm{~m}^{2}$ area).

\section{Temperature measurements}

Temperature gradients are higher at all the measured stations of the MAF $\left(0.14\right.$ to $1.16^{\circ} \mathrm{C}$ $\left.\mathrm{m}^{-1}\right)$ than at the reference site $\left(0.08^{\circ} \mathrm{C} \mathrm{m}^{-1}\right)$ except at Stn 2 where the gradient is similar to that at the reference site. The excess temperature at $0.4 \mathrm{~m}$ depth is not uniform through the area of measurements, however. Stns 1 to 3 have a low anomaly, less than $0.04^{\circ} \mathrm{C}$, while Stns 4 to 8 have temperature excesses greater than $0.07^{\circ} \mathrm{C}$ (Figs. $8 \mathrm{~A}$ and $7 \mathrm{~B}$ ). The highest temperature excess was recorded in the central part of the MAF (Stn 7), where the temperature anomaly reaches up to $0.44^{\circ} \mathrm{C}$.

Stns 1 to 4 are in an area characterized by a high slope, mudstone outcrops and a small amount of mud. Clam distribution is patchy; at Stns 1 to 3 clams are in small localized clusters $\left(\leq 0.5 \mathrm{~m}^{2}\right)$ of high density (125 to 550 ind. $\left.\mathrm{m}^{-2}\right)$. At Stn 4, numerous dense clusters (875 ind. $\mathrm{m}^{-2}$ ) cover $50 \%$ of a $10 \mathrm{~m}^{2}$ area. A cover of black 

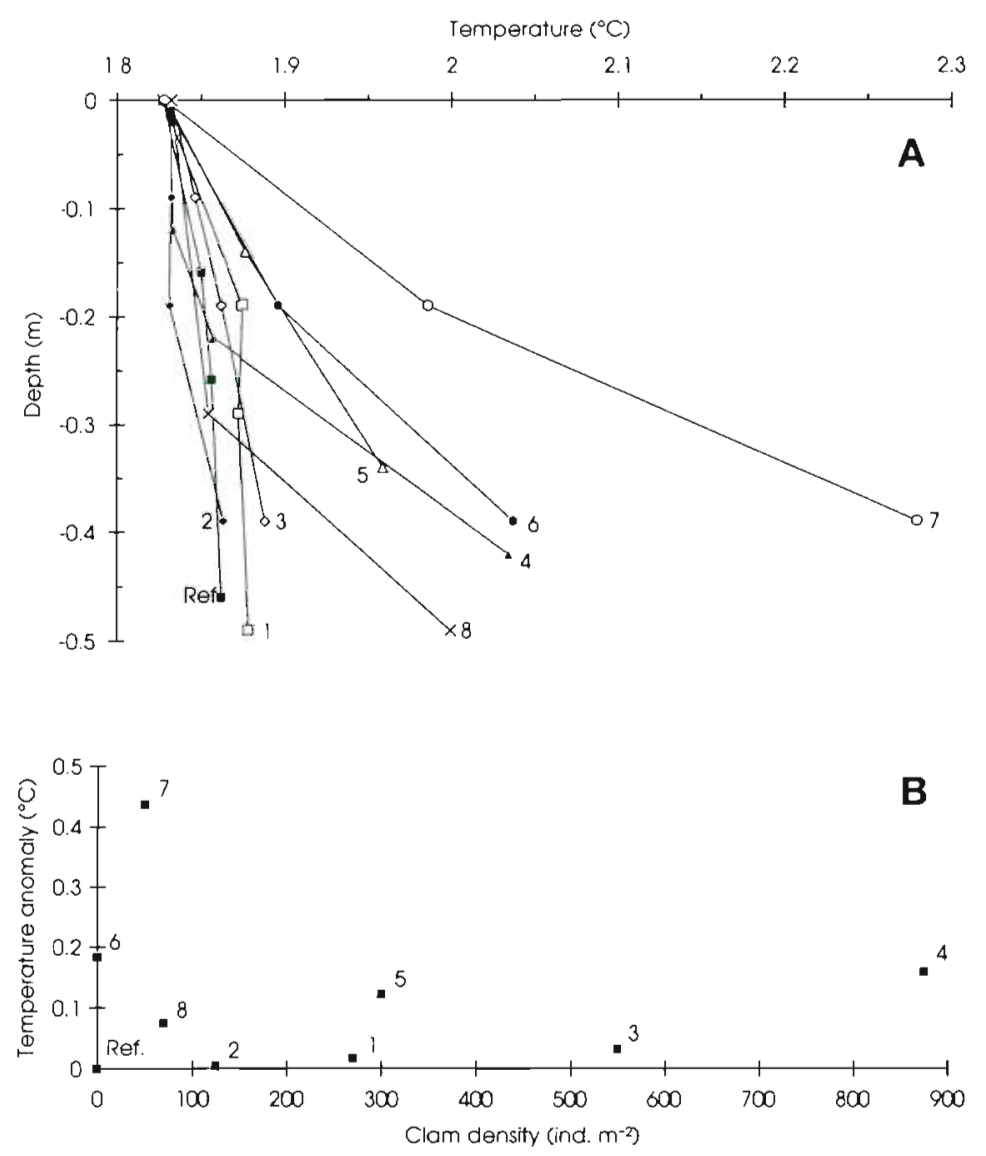

Fig. 8. (A) Temperature data measured with the 'T-Naut' probes at different depths within the sediment. (B) Temperature anomaly (excess) versus clam density at 8 stations of the MAF. Anomalies are calculated from the temperature at $0.4 \mathrm{~m}$ depth into the sediment at the considered site, related to the temperature at the reference site at $0.4 \mathrm{~m}$. Locations of measurements shown in Fig. 7B

mud indicates a reducing sediment that can be attributed to the high biological activity. Stns 5 to 8 are located in a relatively flat area, bound to the east by a muddy area and to the west by serpulids. More mud covers the debris here than at Stns 1 to 4 . Clam distribution is patchy at Stns 5 and 6 ; temperature 5 was measured in a small dense cluster of clams, and temperature 6 in a bare area, near Stn 5. Stns 7 and 8 are in an area of about $10 \mathrm{~m}^{2}$ that is uniformly covered by 50 to 70 clams $\mathrm{m}^{-2}$.

\section{Estimated biomass of bivalves}

Mean clam density in the field is estimated to be 39.5 ind. $\mathrm{m}^{-2}$ (Table 1). Lengths of individual bivalves collected from the MAF were between 11.2 and $18.6 \mathrm{~cm}$, with a mean length of $15.2 \mathrm{~cm}( \pm 2 \mathrm{~cm})$. The wet weight without shell of a $15 \mathrm{~cm}$ length clam is about $52 \mathrm{~g}$; individual weights ranged between 43.1 and $63.5 \mathrm{~g}$ for 9 clams. Using this range of individual weight and the mean clam density of the MAF, the total biomass of the field is estimated to be between 1.7 and $2.5 \mathrm{t}$ in wet weight without shells. No small individuals were sampled although dense clusters seem to contain small individuals. The biomass is therefore probably overestimated. Locally, the biomass of bivalves could reach $29 \mathrm{~kg} \mathrm{~m}^{-2}$ (if we consider dense clusters of $1000 \mathrm{ind} . \mathrm{m}^{-2}$ with individuals of $11.2 \mathrm{~cm}$ length) to $50 \mathrm{~kg}$ $\mathrm{m}^{-2}$ (if $15 \mathrm{~cm}$ length clams are arranged in dense clusters of 1000 ind. $\mathrm{m}^{-2}$ which seems less probable).

\section{Non-symbiotic megafauna}

Other taxa were observed in the clam beds; their abundance and diversity vary among the different types of communities observed along the margin

In clam communities along the TS and on the deepest part of the MSS that are composed of clusters of 10 to 100 individuals of Calyptogena n. sp. 1, pennatulids and amphipods are the only taxa always observed in the seeps, despite the high number of taxa observed around the clam beds. Holothurians (Scotoplanes sp.) are sometimes aggregated in the vicinity of the clams. A few galatheid crabs and shrimps colonize the seeps and occasional octopuses were observed where the number of bivalves reaches 50 to 100 individuals.

Beds of less than 50 Vesicomyidae living at the bend of the MSS contain only a few small serpulid thickets, as well as tube dwelling polychaetes, actinians and a few galatheid crabs.

Megafaunal diversity is fairly high in the MAF, and the taxa display various trophic behaviours (Table 2). Serpulids of the genus Neovermilia are aggregated in large clumps of 20 to $30 \mathrm{~m}^{2}$ and cover $20 \%\left(200 \mathrm{~m}^{2}\right)$ of the MAF. Smaller thickets are attached to the bare rocks of the lower part of the scarps which bound the field. Actinians, holothurians and tube dwelling polychaetes are almost always associated with live clams whereas pennatulids and polychaetes were found near dead bivalves. Caprellid amphipods including Abyssicaprella galatheae (D. Laubitz pers. comm.) swimming in the vicinity of the clams are extremely numerous. The amphipod Stephonyx sp. (S. France pers. comm.) was collected in the MAF. The sampled fauna includes a new species of gastropod of the genus Neolepetopsis (A. Warén pers. comm.). The galatheid Munidopsis 
Table 2. Inventory of benthic organisms sampled or observed on videoscopics or photographic records in the main active field (MAF) and their trophic strategies

\begin{tabular}{|c|c|c|}
\hline Trophic strategies & Taxa & Species \\
\hline Symbiotic species & $\begin{array}{l}\text { Bivalvia, Vesicomyidae } \\
\text { Bivalvia, Solemyidae } \\
\text { Pogonophora }\end{array}$ & $\begin{array}{l}\text { Cf. Calyptogena n. sp. } 2 \\
\text { Cf. Calyptogena n. sp. } 1 \\
\text { Acharax sp. }\end{array}$ \\
\hline Commensal species & $\begin{array}{l}\text { Copepoda, Clausidiidae } \\
\text { Polychaeta, Nautiliniellidae }\end{array}$ & Hyphalion tertium n. sp. \\
\hline $\begin{array}{l}\text { Suspension feeders } \\
\text { encrusting clam shells }\end{array}$ & Bryozoa, Arachnidiidae & Arachnoidea brevicaudata \\
\hline Suspension feeders & $\begin{array}{l}\text { Polychaeta, Serpulidae } \\
\text { Pennatulacea } \\
\text { Polychaeta (tubicolous) } \\
\text { Cirripedia, Scalpellidae } \\
\text { Crinoidea } \\
\text { Actiniaria (red) } \\
\text { Actiniaria (black) }\end{array}$ & $\begin{array}{l}\text { Neovermilia n. sp. } \\
\text { Arcoscalpellum galapaganum }\end{array}$ \\
\hline Deposit feeders & $\begin{array}{l}\text { Asteroidea } \\
\text { Holothuroidea }\end{array}$ & \\
\hline Omnivores & Amphipoda, Caprellidae & Abyssicaprella galatheae \\
\hline Carnivores/scavengers & $\begin{array}{l}\text { Amphipoda, Lysianassoidae } \\
\text { Gastropoda, Pseudococculinidae } \\
\text { Galatheidae } \\
\text { Decapoda, Natantia } \\
\text { Octopoda, Octopodidae } \\
\text { Macrouridae } \\
\text { Zoarcidae }\end{array}$ & $\begin{array}{l}\text { Stephonyx sp. } \\
\text { Neolepetopsis n. sp. } \\
\text { Munidopsis crassa } \\
\text { Benthoctopus sp.-like } \\
\text { Coryphaneoides sp. }\end{array}$ \\
\hline
\end{tabular}

crassa (M. de Saint Laurent, pers. comm.) is also abundant. An octopus likely belonging to the genus Benthoctopus (A. Guerra pers. comm.) was seen in dense clam clusters (Fig. 4c). Macrourid and zoarcid fishes are relatively numerous in the MAF.

\section{DISCUSSION}

\section{Vesicomyid species distribution}

The communities associated with fluid expulsion observed along the northern Peruvian margin are dominated by vesicomyid bivalves, living in symbiosis with chemoautotrophic sulfur-oxidizing bacteria. Although they rely on a similar energy source, the spatial distribution of the 3 species of bivalves is different along the margin. The smallest species, Vesicomya n. sp., is observed only at 2 sites, at 2600 and $3300 \mathrm{~m}$. Calyptogena n. sp. 2 lives between 2600 and $3400 \mathrm{~m}$, whereas Calyptogena n. sp. 1 lives mainly between 4000 and $5200 \mathrm{~m}$ and never above $3500 \mathrm{~m}$. At the bend of the MSS, around $3550 \mathrm{~m}$, both species of Calyptogena co-occur, but Calyptogena n. sp. 2 is dominant. Different physiological tolerances to pressure might result in this depth distribution, and inter- specific competition could occur at the depth where both species can live, i.e. around $3500 \mathrm{~m}$. In Japanese cold seeps, only 1 species, C. phaseoliformis, is present in the deepest part (Juniper \& Sibuet 1987), whereas 3 other species of Vesicomyidae live in shallower areas.

Other hypotheses have been proposed to explain the spatial distribution of co-occurrent bivalve species in other cold seep settings. Different sources of fluids may explain the distribution of Calyptogena sp. and Solemya sp. beds in the Cascadia subduction zone (Lewis \& Cochrane 1990). Different concentrations of reduced compounds in the fluid may explain the spatial distribution of Vesicomya gigas and C. pacifica in Monterey Bay, because the 2 species may differ in their sulfide tolerances and sulfide binding abilities (Barry et al. 1994). In the Paita area, chemical analyses indicate that a unique continental source is providing most of the fluids expelled at venting sites (Dia et al. 1993). The variations in potassium and trace metal (manganese and lithium) concentrations that exist are assumed to be due to differences in plumbing systems and not to different origins of the fluid (Dia et al. 1994); they may influence the distribution of the Vesicomyidae along the margin, however. Sibuet et al. (1990), Henry et al. (1992) and Lallemant et al. (1994) 
suggested that species composition and clam density are related to the temperature gradient in the Nankai accretionary wedge. Differences in fluid flow could also influence colonization of a seep area by a species of Calyptogena. Because in our study the temperature measurements were only taken in communities dominated by Calyptogena n. sp. 2, we cannot conclude whether species composition is related to fluid flow differences. Therefore, the most likely hypothesis to explain the spatial distribution of Vesicomyidae in the Paita area is that the Vesicomyidae have different depth or chemical tolerances towards elements like metals and sulfide.

\section{Localization of the chemosynthetic communities as indicators of fluid expulsion}

\section{Along the Paita area}

Fluid circulation was considered, from geological observations, to be dependent on the east-west trending fault system of the continental basement (Duperret et al. 1993, Sosson et al. 1994). Fluids of continental origin may be channeled from upslope locations to downslope locations along the canyons of the USS, along the scar of the debris avalanche (MSS) and along the contact between the continental and oceanic plates at the TS (Dia et al. 1993). The spatial distribution of chemosynthetic communities indicates locations where fluids are expelled along the 3 scarps. Fluid seepages occur along the fractured part of the scarps and are precluded by a thick sediment cover, as in the lower part of the canyons and in the deepest part of the TS. The occurrence of a large active clam field at the bend of the MSS suggests that this scarp is the place of large fluid expulsion.

\section{At the bend of the MSS}

The spatial distribution of clam beds is strongly linked to tectonic features along the scarp: fractures, joints, recent little scars and fresh screes. The occurrence of clam beds in a wide area at approximately the same depth suggests that these communities could be sustained by fluid drained by a well-developed network of fractures within the margin. This network can be considered as an 'aquifer', which is supplied by fluids that escape along fractures and drain along the canyons of the USS. The presence of dead clam beds in some places and the small size (less than $1 \mathrm{~m}^{2}$ ) of the clam beds suggest fluid input is irregular over time. The MSS contains recent scars and fresh screes related to slope instabilities. Moreover, seismic activity is high along the margin and may partly control fluid expulsion. Such irregular fluid impulse may favour the settlement of sporadic communities composed by ephemeral clam beds along the fractured scarps. The observation of a large active field (about $1000 \mathrm{~m}^{2}$ ) with high clam densities, on a step of the scarp at the intersection of 2 faults, suggests however the occurence of high fluid expulsion at this location.

\section{Evidence of high chemosynthetic production linked to high fluid flow in the MAF}

The density of bivalves (mean density of 40 ind. $\mathrm{m}^{-2}$, locally up to 1000 ind. $\mathrm{m}^{-2}$ ) and the estimated biomass of the MAF (about $2 \mathrm{t}$ in totality, up to about $30 \mathrm{~kg} \mathrm{~m}^{-2}$ ) are very high and continuous over a large area. Such a high chemosynthetic production is likely sustained by a high fluid flow. Evidence for high fluid flow may be found from measurements of abnormally high temperature gradients below the communities (see the study conducted for Japanese seeps by Henry et al. 1992). Although a thermal model has not yet been constructed for the MAF, a first estimate gives a minimum flow rate of $400 \mathrm{~m} \mathrm{yr}^{-1}$ in the central part of the field. This calculation is based on the following consideration: the measurement of significant temperature excess at shallow depth in the sediment means that the process of heat supply by the moving fluid at this depth dominates heat dissipation by conductive cooling, or that the time for conductive cooling to propagate from the seafloor to a depth of $0.4 \mathrm{~m}$ below the seafloor is larger than the time the fluid takes to flow from this depth to the surface. The time for conductive cooling is $l^{2} / d$, i.e. $9 \mathrm{~d}$ with $l=0.4 \mathrm{~m}$ and $d=2 \times 10^{-7} \mathrm{~m}^{2} \mathrm{~s}^{-1}$ (thermal diffusivity of sediment). The fluids are assumed to flow preferentially in the higher permeability depth intervals between the mudstone beds that are nearly parallel to the seafloor and extend laterally in the MAF. Taking a flow path in the depth interval 0 to $0.4 \mathrm{~m}$ over at least $10 \mathrm{~m}$, the lowest flow rate permitted (considering the time for conductive cooling) is then $1.1 \mathrm{~m} \mathrm{~d}^{-1}$ or about $400 \mathrm{~m} \mathrm{yr}^{-1}$. This value is comparable to fluid flow velocities of $583 \mathrm{~m} \mathrm{yr}^{-1}$ determined in the MAF from measurements of the barium flux (Linke et al. 1994). These values are in order of magnitude of the velocities reported for other known cold seeps on active margins, along the Cascadia margin (1023 to $1065 \mathrm{~m} \mathrm{yr}^{-1}$ ) and in Nankai Trough off Japan (100 m $\mathrm{yr}^{-1}$ ) (Henry et al. 1992).

The biomass value of $30 \mathrm{~kg} \mathrm{~m}^{-2}$ is comparable to the biomass reported by Hessler \& Smithey (1983) for Bathymodiolus thermophilus from Galapagos hydrothermal vents ( 10 to $15 \mathrm{~kg} \mathrm{~m}^{-2}$ wet weight). High biomasses have been observed for Vesicomyidae popula- 
tions in other cold seep settings, as in Sagami Bay (Japan) (10 $\mathrm{kg} \mathrm{m}^{-2}$ in wet weight) (Hashimoto et al. 1989) and in Japanese trenches (16 to $51 \mathrm{~kg} \mathrm{~m}^{-2}$ in wet weight including shells) (Ohta \& Laubier 1987). High bivalve densities have also been reported by these authors, up to 1000 ind. $\mathrm{m}^{-2}$ in Sagami Bay and up to 2000 ind. $\mathrm{m}^{-2}$ within 'nurseries' of the Japanese trenches. MacDonald et al. (1990b) observed densities of 800 ind. $\mathrm{m}^{-2}$ for Mytilidae sustained by hydrocarbon seepages in the Gulf of Mexico. All these reported biomasses occur on spatially restricted or discontinuous areas, however. MacDonald et al. (1990a) observed Mytilidae along the Louisiana continental slope in clusters 2 to $5 \mathrm{~m}$ across with welldefined edges. Clam beds are sporadically dispersed in Japanese trenches (Sibuet et al, 1988) where bed size is generally less than $5 \mathrm{~m}^{2}$ and up to only $20 \mathrm{~m}^{2}$. Except for the Hatsushima site in Sagami Bay, where a large clam bed $(200 \mathrm{~m}$ by $30 \mathrm{~m}$ ) is formed by small patches, the distribution of cold seep communities is not continuous. The patchy and ephemeral occurrence of chemosynthetic fauna in hydrothermal vents and cold seep settings has been widely attributed to spatial and temporal variations in the fluid supply (Hessler et al. 1985, Suess et al. 1985, Fustec et al. 1987. Sibuet et al. 1988, MacDonald et al. 1989, Jollivet 1993). In the Paita area, the existence of a $1000 \mathrm{~m}^{2}$ continuous field is consistent with more regular and more diffuse fluid expulsion than generally occurs in other explored cold seep areas.

\section{Influence of environmental conditions on the microdistribution of bivalves}

Temperature data suggests that fluid expulsion is markedly active in the central MAF; however, temperature gradient shows local variations in the MAF (Fig. 7). Clam microdistribution may be influenced by these variations. At Stns 1. to 4, clam density is related to temperature excess (Fig. 8B). This relation is not verified for other stations, however. At Stn 6, high flow was measured in a surface devoid of clams but near a dense clam bed that likely used this discrete emission. The stations with highest temperature anomalies that are located at the center of the field (Stns 4 to 8) have variable clam densities. For example, although Stns 4 and 7 have similar temperature gradients, clam density is 10 times higher at $\operatorname{Stn} 4$ than at $\operatorname{Stn} 7$ (Fig. $8 B$ ). The greater mud cover at Stns 7 and 8 may favour fluid diffusion into the superficial layer of sediment thereby producing a homogeneous area of fluid expulsion. At these stations, clams are homogeneously distributed over a large area and are at intermediate densities. In contrast, the patchy distribution of clams at other sites indicates more localized fluid seeps, as in Stns 1 to 3, where fluids are assumed to be expelled under flat slides of mudstones that outcrop in this steep area. The fluid diffusion is thereby influenced by the nature of the sediment in the upper layer, for example by the thickness of the mud cover or by the occurrence of fluid-driving sedimentologic features such as mudstone plates. Tectonic features such as subsurface faults could also have this function, as described at larger scale (Sibuet et al. 1988, MacDonald et al. 1989, Lewis \& Cochrane 1990, this paper). A mud cover which is too thick could preclude fluid expulsion as shown by the decrease of clam density from the central to the lower part of the field corresponding with the increase of mud. The occurrence of dead clams and dead serpulids in this part of the field may indicate that this location was active before the upper part, or that fluid expulsion has decreased or stopped only in this part of the MAF.

The thickness and porosity of the sediment could also have a direct influence on the bivalve settlement as clams need to have their siphon in contact with a sufficiently high permeability zone in the sediment to take up sulfide by their foot. In the MAF, clams seem to respond to variations of thickness of the mud cover, being more or less buried. This adaptative behaviour could not occur however where the thickness of mud is too great and probably deeper than the clam's shell length.

Calyptogena sp. likely responds to variability of the fluid flow but also of the concentration of reduced elements (methane and sulfide) in the fluid and/or on the production of sulfide in the surface sediment. No comparative measurements of these different chemical compounds were made at the scale of the MAF; their concentration in the primary fluid probably does not vary at this scale as the chemical composition of the fluid is very similar all along the margin (Dia et al. 1993). However, the activity of sulfate-reducing bacteria in the sediment could differ from place to place and thus produces a variable quantity of sulfide available for sulfur-oxidizing clam symbionts. In the same way, MacDonald et al. (1989) suggested a spatial discontinuity in sulfide production in sediments to explain the fine-scale distribution of vestimentiferan tube worms in Gulf of Mexico hydrocarbon seeps. Oxygen concentration in seawater is also considered as a limiting factor particularly in very dense beds and/or on areas without current. For example, microdistribution patterns of Bathymodiolus-like mussels in hydrocarbon seeps are attributed by MacDonald et al. (1990b) to an equilibrium between methane and oxygen concentration in seawater. Observations made during dives indicate that the MAF seems to be welloxygenated by the bottom currents. 


\section{Community structure including non-symbiotic organisms}

The communities are characterized by the dominance of Calyptogena sp. and by the common occurrence of other species in association with the clams. Species that compose seep communities can be classified according to their spatial distribution with respect to the area affected by fluid seepage (Carney 1994). Some species may be endemic to the chemosynthetic communities; they are generally symbiotic species or other species strongly linked to fluid expulsion. Some may be colonists from the surrounding benthos, which have higher densities in the seep community than outside, or vagrants, which have the same abundance inside the seeps as outside seep areas. Although it is difficult to classify seep organisms into these categories because of the lack of knowledge of the surrounding fauna, the distinction between colonists and vagrants could be deduced from video and photo records. Most observed species of the TS communities such as pennatulids, amphipods and holothurians (Scotoplanes sp.) seem to be colonists. Galatheid crabs could be considered as colonists while shrimps and octopuses are likely vagrants. In the MAF, except fishes and octopuses that seem to be vagrants, numerous species are endemics or colonists. At least 4 symbiotic species are endemics of the seep community, both Calyptogena n. sp., the solemyid Acharax sp. (see Reid \& Barnard 1980, Cavanaugh 1983 and Kusnetsov et al. 1990 for symbiosis of Solemyidae) and 1 pogonophoran (see Southward et al. 1981 for symbiosis of pogonophorans). Actinians, pennatulids and the galatheid Munidopsis crassa are colonists. As serpulids were never observed outside of the clam communities, they are suspected to be endemics; if not, they are colonists. Finally, the gastropod Neolepetopsis $\mathrm{n}$. $\mathrm{sp}$. is very likely endemic, as Neolepetopsis (A. Warén pers. comm.) belongs to a family of hydrothermal vent limpets.

The increase in local production by means of the chemoautotrophic bacteria/bivalve symbiosis is attractive to these other taxa (Table 2). The most common organisms are deposit and suspension feeders; they likely benefit from possible high concentration of organic matter in the sediment. The serpulid genera Neovermilia is widespread in abyssal areas, but the aggregations observed in the Paita area are unusual (H. Zibrowius pers. comm.) (Fig. 4b) because thickets are exceptionally large (160 to $200 \mathrm{~m}^{2}$ in totality), individual tubes are long (more than $20 \mathrm{~cm}$ ), and because worm densities are high in the clusters, so high that tubes stick to each other. High densities of serpulids have been found in hydrothermal vent areas (Hessler \& Smithey 1983), but tube lengths do not exceed $10 \mathrm{~cm}$ (ten Hove \& Zibrowius 1986). An additional trophic source is necessary to explain the high serpulid densities observed on the Peruvian margin compared to those observed outside seeps on the deep sea floor. Desbruyères et al. (1985) have found filamentous bacteria attached to the digestive tubes of some specimens of hydrothermal serpulids. Absence of chemoautotrophic bacteria in tissues of the Peruvian specimens observed by transmission electron microscopy (TEM) suggests however that symbiosis is unlikely. Serpulids are moreover usually considered suspension feeders (Fauchald \& Jumars 1979). This feeding mode is confirmed by the well-developed and widely unfolded branchial crown of hydrothermal vent serpulids (ten Hove \& Zibrowius 1986) and of the Peruvian margin serpulids. In the MAF, their survival depends on the fluid expulsion because they do not survive where fluid emission seems reduced, as in the lower part of the field, where numcrous individuals of Calyptogena sp. are dead. Filtration of resuspended particulate organic matter produced by the chemosynthetic activity is therefore the most probable trophic strategy for these organisms. Bacterial mats probably composed of the filamenteous Beggiatoa sp. have been observed near serpulid clumps. The autotrophic or heterotrophic free-living bacteria in sediment or water may contribute to the nutrition of the serpulids. As proposed for Japanese cold seeps (Juniper \& Sibuet 1987), the cooccurrence of 2 parallel trophic chains is likely: one part of the primary production is ensured by symbiotic bacteria, and another part by free-living bacteria.

Amphipods and galatheids are present in each of the clam beds, and gastropods, fishes and octopuses occur in the larger beds. In the MAF, scavengers and predators are numerous compared to in cold seeps on the Barbados prism (Jollivet et al. 1990), along the Oregon margin (Kulm et al. 1986) and along Japanese trenches (Juniper \& Sibuet 1987). Because of the relative abundance of predators, the main field of the Paita area might be compared to some complex hydrothermal communities. The abundance of predators could be attributed on one hand to the high clam density; nevertheless, the low percentage of clam shells suggests a low mortality by predation. The exceptional development of serpulids could on the other hand explain the abundance of predators, as has been proposed for some east Pacific hydrothermal vent communities (Fustec et al. 1987).

\section{Maturity of Peruvian cold seep communities}

The maturity of an ecosystem can be expressed by biomass, size distribution, species richness, diversity of the feeding strategies and complexity of the trophic structure (Frontier \& Pichod-Viale 1991). Along the 
Peruvian margin, cold seep communities can be classified according to their stage of maturity, using biomass of symbiotic species (characterized by the size and density of clam beds), species diversity (symbiotic and non-symbiotic species) and diversity of the trophic strategies. Some communities might be defined as juvenile: for example, the least mature community lives at the bend of the MSS and consists of small sparse clam beds of low clam density. Clams are within a narrow size-range and the few colonists are suspension feeders (except a galatheid crab). Instability of the fluid emission could explain the occurrence of such an ephemerous community. In contrast, the MAF community is more mature; it has high biomass, a large sizerange of bivalves and many species with various trophic stategies (13 sampled, 11 observed but probably other meiofauna and macrofauna species are present). This community includes numerous colonists and several non-symbiotic species that may be endemic to the seep community. Establishment of such a mature ecosystem is probably possible only if the field is sustained by constant fluid flow. Finally, communities in intermediate stages of maturity have been observed along the Peruvian margin: for example, communities in the deepest part of the Paita area have intermediate levels of bivalve biomass, low species diversity, and, particularly in the largest clam beds, species with more various trophic behaviours than juvenile systems (e.g. suspension and deposit feeding, some predation).

\section{CONCLUSION}

This study is the first description of the spatial distribution of cold seep benthic communities along an erosive margin, on a long transect $(40 \mathrm{~km})$ and across a wide bathymetric range $(2600$ to $5300 \mathrm{~m})$. Three species of Vesicomyidae co-occur along the margin and have different spatial distributions. The spatial ranges of the 2 dominant species, both related to the genus Calyptogena, seem to be mostly related to different physiological depth tolerances. The distribution of clam beds is indicative of the spatial organization of the fluid expulsion network at different scales. At the scale of the whole Paita area, fluids escape from the canyons of the upper slope, along the MSS and the steepest part of the TS. At a smaller scale on the scarps, fluids are expelled at fractures and joints. Numerous clam beds and the largest active field are located at the bend of the MSS where fluids extrude from a network of fractures that probably form a kind of aquifer within the margin. In some locations, a thick mud cover precludes fluid expulsion. The microdistribution of bivalves seems to be related to the small spatial scale variability in the fluid flow, whose diffusion is controlled by the nature of subsurface sediment.

Clam bed size, clam density and species richness of the accompanying fauna depend on the regularity and duration of the fluid emission. At some places along the margin, the occurrence of ephemerous communities suggests that fluids are expelled sporadically. This irregular fluid input may be controlled by the high seismic activity recorded along the Peruvian margin. At the bend of the MSS, the occurrence of a large active field with high biomass (ca $2 \mathrm{t}$ of clams in wet weight) and the diverse faunal community is linked to a high fluid flow (about $400 \mathrm{~m} \mathrm{yr}^{-1}$ ) assumed to be temporally regular.

Acknowledgements. We are indebted to the captain and crew of N/O 'Nadir', to the 'Nautiperc' cruise scientists, pilots and crew of the submersible 'Nautile' for collecting the faunal samples during the dives. We particularly thank Jacques Bourgois for inviting one of us on this cruise and permitting the ecological study. We thank J.-M. Raillard for his contribution on the navigation processing, C. Lambert, P. Chevaldonné, P.-M. Sarradin for helpful comments, R. P. Carriol, S. France, A. Guerra, D. Laubitz, B. Métivier, M. de Saint Laurent, A. Warén and $\mathrm{H}$. Zibrowius for species identifications and valuable information, and anonymous reviewers for helpful comments on the manuscript

\section{LITERATURE CITED}

Aubouin J, Bourgois J, Azema J (1984) A new type of active margin: the convergent-extensional margin, as exemplified by the middle America trench of Guatemala. Earth Planet Sci Lett 87:111-126

Barry JP, Kochevar RE, Baxter CH, Whaling PJ (1994) Distribution and growth rates of vesicomyid clams in relation to pore water chemistry of cold seeps in Monterey Bay, California, USA. Seventh Deep Sea Symposium, Heraklion, Crete. IBMC, Heraklion

Boulègue J, Le Pichon X, Liyama JT (1985) Prévision des tremblements de terre dans la région de Tokai (Japon). C R Acad Sci Ser II 301:1217-1219

Boulègue J, Mariotti A, Fiala A, Bourgois J (1992) Geochemistry of clams from subduction zones. EOS 73:153

Bouma AH, Roberts HH (1990) Northern Gulf of Mexico continental slope. Geo-Mar Lett 10:177-181

Bourgois J, Lagabrielle Y, De Wever P, Suess E (1993) Tectonic history of the northern Peru convergent margin during the past $400 \mathrm{ka}$. Geology 21:531-534

Bourgois J, Pautot $G$, Bandy W, Boinet $T$, Chotin $P$, Huchon $P$, Mercier de Lepinay B, Monge F, Monlaü J, Pelletier B. Sosson $M$, von Huene R (1986) Régime tectonique de la marge andine convergente du Pérou (Campagne SEAPERC du N.O. Jean Charcot, juillet, 1986). C R Acad Sci Ser ll 303:1599-1604

Brooks JM, Kennicutt MC II, Fisher CR, Macko SA, Cole K, Childress JJ, Bidigare RR, Vetter RD (1987) Deep-sea hydrocarbon seep communities: evidence for energy and nutritional carbon sources. Science 238:1138-1142

Cadet JP, Kobayashi $K$, Aubouin J, Boulègue J, Deplus C, Dubois J, von Huene R, Jolivet L, Kanazawa T, Kasahara J, Koizumi K, Lallemand S, Nakamura Y, Pautot G, Suyehiro K, Tani S, Tokuyama H, Yamazaki T (1987) The Japan Trench and its juncture with the Kurile Trench: cruise 
results of the Karko project, Leg 3. Earth Planet Sci Lett $83: 267-284$

Carney RS (1994) Consideration of the oasis analogy for chemosynthetic communities at Gulf of Mexico hydrocarbon vents. Geo-Mar Lett 14:149-159

Cary C, Fry B, Felbeck H, Vetter RD (1989) Multiple trophic resources for a chemoautotrophic community at a cold water brine seep at the base of the Florida Escarpment. Mar Biol 100:411-418

Cavanaugh CM (1983) Symbiotic chemoautotrophic bacteria in marine invertebrates from sulphide-rich habitats. Nature 302:58-61

Desbruyères D, Gaill F, Laubier L, Fouquet Y (1985) Polychaetous annelids from hydrothermal vent ecosystems: an ecological overview. Bull Biol Soc Wash 6:103-116

Dia A, Aquilina L, Boulègue J (1994) Geochemical evidence of continental fluid circulation in the Peru subduction zones. Mineral Mag 58A:225-226

Dia A, Aquilina L, Boulègue J, Bourgois J, Suess E, Torres M (1993) Origin of fluids and related barite deposits at vent sites along the Peru convergent margin. Geology 21: $1099-1102$

Duperret A, Bourgois J, Lagabrielle Y, Suess E (1995) Slope instabilities at an active continental margin: large-scale polyphase submarine slides along the northern Peruvian, between $5^{\circ} \mathrm{S}$ and $6^{\circ} \mathrm{S}$ latitude. Mar Geol 122:303-328

Duperret A, Lagabrielle Y, Bourgois J (1993) Résultats des plongées du Nautile sur la marge continentale du Pérou à $5^{\circ} 40^{\prime}$ S: étude de la zone d'arrachement d'un méga-glissement sous-marin (campagne NAUTIPERC, 1991). C R Acad Sci Ser II 316:371-378

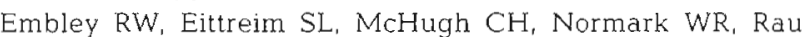
GH, Hecker B, DeBevoise AE, Greene HG, Ryan WBF, Harrold C, Baxter C (1990) Geological setting of chemosynthetic communities in the Monterey Fan Valley system. Deep Sea Res 37:1651-1667

Fauchald K, Jumars PA (1979) The diet of worms: a study of polychaete feeding guilds. Oceanogr Mar Biol A Rev 17: $193-284$

Faugères JC, Gonthier E, Griboulard R, Jollivet $D$, Vernette $G$ (1990) Morphology, microphysiography, sedimentary, and biology patterns of surficial deposits in the south Barbados prism: record of recent and present active tectonics. Proc Ocean Drilling Program Sci Results 110: $111-126$

Fiala-Médioni A, Le Pennec M (1988) Structural adaptation in the gill of the Japanese subduction zone bivalves (Vesicomyidae) Calyptogena phaseoliformis and Calyptogena laubieri. Oceanol Acta 11:1.85-192

Fiala-Médioni A, Sibuet $M$, Segonzac $M$, Bourgois J, the 'Nautiperc' scientific crew (1992) Biological communities associated with cold vents in the Peru Trench (Abstract) EOS 73:153

Frontier S, Pichod-Viale D (1991) Ecosystèmes: structure, fonctionnement, evolution. Masson, Paris

Fustec A, Desbruyères D, Juniper SK (1987) Deep-sea hydro thermal vent communities at $13^{\circ} \mathrm{N}$ on the East Pacific Rise microdistribution and temporal variations. Biol Oceanogr 4:121-164

Hashimoto J, Matsuzawa S, Hotta H (1988) Searching for biological communities at the Okinoyama bank site, the Sagami Bay. JAMSTECTR Deepsea Res 4:177-188

Hashimoto J, Ohta S, Tanaka T, Hotta H, Matsuzawa S, Sakai $\mathrm{H}$ (1989) Deep-sea communties dominated by the giant clam, Calyptogena soyoae, along the slope foot of Hatsushima Island, Sagami Bay, central Japan. Palaeogeogr Palaeoclimatol Palaeoecol 71:179-192
Hecker B (1985) Fauna from a cold sulfur-seep in the Gulf of Mexico: comparison with hydrothermal vent communities and evolutionary implications. Bull Brol Soc Wash 6: $465-4.73$

Henry P, Foucher JP, Le Pichon X, Sibuet M, Kobayashi K, Tarits P, Chamot-Rooke N, Furuta T, Schultheiss P (1992) Interpretation of temperature measurements from the Kaiko-Nankai cruise: modeling of fluid flow in clam colonies. Earth Planet Sci Lett 109:355-371

Henry P, Le Pichon X, Lallemant S, Foucher JP, Westbrook G, Hobart M (1990) Mud volcano field seaward of the Barbados accretionary complex: a deep-towed side scan sonar survey. J Geophys Res 95:8917-8929

Hessler RR, Smithey WM Jr (1983) The distribution and community structure of megafauna at the Galapagos rift hydrothermal vents. In: Rona PA, Bostrom $K$, Laubier L, Smith KL Jr (ed) Hydrothermal processes at seafloor spreading centers. Plenum Publishing Corporation, New York, p $735-770$

Hessler RR, Smithey WM Jr, Keller CH (1985) Spatial and temporal variation of giant clams, tube worms and mussels at deep-sea hydrothermal vents. Bull Biol Soc Wash 6: $411-428$

Jollivet D (1993) Distribution et evolution de la faune associée aux sources hydrothermales profondes à $13^{\circ} \mathrm{N}$ sur la dorsale du Pacifique oriental: le cas particulier des polychetes Alvinellidae. Thèse de doctorat, Université de Bretagne Occidentale, Brest

Jollivet D, Faugères JC, Griboulard R, Desbruyères D, Blanc G (1990) Composition and spatial organization of a cold seep community on the south Barbados accretionary prism: tectonic, geochemical and sedimentary context. Prog Oceanogr 24:25-45

Juniper SK, Sibuet M (1987) Cold seep benthic communities in Japan subduction zones: spatial organization, trophic strategies and evidence for temporal evolution. Mar Ecol Prog Ser 40:115-126

Kennicutt MC II, Brooks JM (1990) Recognition of areas affected by petroleum seepage: northern Gulf of Mexico continental slope. Geo-Mar Lett 10:221--224

Kennicutt MC II, Brooks JM, Bidigare RR, Fay RR, Wade TL, McDonald TJ (1985) Vent-type taxa in a hydrocarbon seep region on the Louisiana slope. Nature 317:351-353

Kennicutt MC II, Brooks JM, Bidigare RR, McDonald SJ, Adkison DL, Macko SA (1989) An upper slope 'cold' seep community: northern California. Limnol Oceanogr 34: $635-640$

Kulm LD, Suess E, Moore JC, Carson B, Lewis BT, Ritger SD, Kadko DC, Thornburg TM, Embley RW, Rugh WD, Massoth GJ, Langseth MG, Cochrane GR, Scamman RL (1986) Oregon subduction zone: venting, fauna and carbonates. Science 231:561-566

Kusnetsov AP, Ohta S, Endow K (1990) Morphofunctional consequences of bacterial symbiotrophy in Solemya (Petrasma) pusilla (Protobranchia, Bivalvia) from Sagami Bay (central Japan). Izv Akad Nauk Ser Biol 6:895-903

Lagabrielle Y, Duperret A, Bourgois J (1992) In-situ structural observations along the inner slope of the Peru trench: preliminary results of the Nautiperc cruise with the submersible Nautile (Abstract). EOS 73:152

Lallemant SJ, Henry P, Le Pichon X, Hotta H (1994) Tectonic context of venting sites at the toe of the eastern Nankai accretionary prism. Deep Sea Res 10:331-341

Laubier L Ohta $S$, Sibuet $M$ (1986) Décowverte de communautés animales profondes durant la campagne francojaponaise KAIKO de plongées dans les fosses de subduction autour du Japon. C R Acad Sci Ser Ill 303:25-29 
Le Pichon X, Liyama T, Chamley $H$, Charvet J, Faure M, Fujimoto H, Furuta T, Ida Y, Kagami H, Lallemand S, Leggett J, Murata A, Okada H, Rangin C, Renard V, Taira A, Tokuyama $H$ (1987) The eastern and western ends of Nankai trough: results of box 5 and box 7 Kaiko survey. Earth Planet Sci Lett 83:199-213

Lewis BTR, Cochrane GC (1990) Relationship between the location of chemosynthetic benthic communities and geologic structure on the Cascadia subduction zone. J Geophys Res B 95:8783-8793

Linke P, Suess E, Torres M. Martens V, Rugh WD, Zoebis W, Kulm LD (1994) in situ measurement of fluid flow from cold seeps at active continental margins. Deep Sea Res 41:721-739

MacDonald IR, Boland GS, Baker JS, Brooks JM, Kennicutt MC Il, Bidigare RR (1989) Gulf of Mexico hydrocarbon seep communities. II. Spatial distribution of seep organisms and hydrocarbons at Bush Hill. Mar Biol 101. 235-247

MacDonald IR, Callender WR, Burke RA Jr, McDonald SJ, Carney RS (1990a) Fine-scale distribution of methanotrophic mussels at a Louisiana cold seep. Prog Oceanogr $24: 15-24$

MacDonald IR, Guinasso NL Jr, Reilly JF, Brooks JM, Callender WR, Gabrielle SG (1990b) Gulf of Mexico hydrocarbon seep communities: Vl. Patterns in community structure and habitat. Geo-Mar Lett 10:244-252

Mayer LA, Shor AN, Hughes Clarke J, Piper DJW (1988) Dense biological communities at $3850 \mathrm{~m}$ on the Laurentian Fan and their relationship to the deposits of the 1929 Grand Banks earthquake. Deep Sea Res 35:1235-1246

Mills EL, Pittman K, Munroe B (1982) Effect of preservation on the weight of marine benthic invertebrates. Can J Fish Aquat Sci 39:221-224

Ohta S, Laubier L (1987) Deep biological communities in the subduction zone of Japan from bottom photographs taken during 'Nautile' dives in the Kaiko project. Earth Planet Sci Lett 83:329-342

Okutani T, Egawa K (1985) The first underwater observation on living habit and thanatocoenoses of Calyptogena soyoae in bathyal depth of Sagami Bay. Venus Jpn J Malacol 44:285-289

Orange DL, Greene HG, Barry J, Kochevar R (1994) ROV investigations of cold seeps along fault zones and mud volcanoes in Monterey Bay. 1994 spring meeting, Baltimore, Maryland. EOS 75:324

Paull CK, Hecker B, Commeau R, Freeman-Lynde RP, Neu-

This article was submitted to the editor mann C, Corso WP, Golubic S, Hook JE, Sikes E, Curray $J$ (1984) Biological communities at the Florida escarpment resemble hydrothermal vent taxa. Science 226 : 965-967

Reid RC, Barnard DG (1980) Gutless bivalves. Science 208:609 Rosman I, Boland GS, Baker JS (1987) Epifaunal aggregations of Vesicomyidae on the continental slope off Louisiana. Deep Sea Res 34:1811-1820

Saino T, Ohta $S(1989){ }^{13} \mathrm{C} /{ }^{12} \mathrm{C}$ and ${ }^{15} \mathrm{~N} /{ }^{14} \mathrm{~N}$ ratios of vesicomyid clams and a vestimentiferan tube worm in the subduction zone east of Japan. Palaeogeogr Palaeoclimatol Palaeoecol 71:169-178

Sakai H, Gamo T, Endow K, Ishibashi J, Ishizuka T, Yanagisawa F, Kusakabe M. Akagi T, Igarashi G, Ohta S (1987) Geochemical study of the bathyal seep communities at the Hatsushima site, Sagami Bay, central Japan. Geochem J $21: 227-236$

Sibuet M, Fiala-Médioni A, Foucher JP, Ohta S (1990) Spatial distribution of clam colonies at the toe of the Nankai accretionary prism near $138^{\circ} \mathrm{E}$. In: Cadet JP, Le Pichon $\mathrm{X}$ (eds) International conference on fluids in subduction zones and related processes, Paris, Nov 5-6, 1990. Ecole Normale Supérieure, Paris

Sibuet $M$, Juniper SK, Pautot G (1988) Cold-seep benthic communities in the Japan subduction zones: geological control of community development. J Mar Res 46:333-348

Sosson M, Bourgois J, Mercier de Lépinay B (1994) Sea Beam and deep-sea submersible Nautile surveys in the Chiclayo canyon off Peru $\left(7^{\circ} \mathrm{S}\right)$ : subsidence and subduction-erosion of an Andean-type convergent margin since Pliocene times. Mar Geol 118:237-256

Southward AJ, Southward EC, Dando PR, Rau GH, Felbeck $\mathrm{H}$. Flügel $\mathrm{H}$ (1981) Bacterial symbionts and low ${ }^{13} \mathrm{C} /{ }^{12} \mathrm{C}$ ratios in tissues of Pogonophora indicate unusual nutrition and metabolism. Nature 293:616-620

Suess E, Carson B, Ritger SD, Moore JC, Jones ML, Kulm LD, Cochrane GR (1985) Biological communities at vent sites along the subduction zone off Oregon. Bull Biol Soc Wash $6: 475-484$

ten Hove HA, Zibrowius H (1986) Laminatubus alvini gen. et sp. n. and Protis hydrothermica sp. n. (Polychaeta, Serpulidae) from the bathyal hydrothermal vent communities in the eastern Pacific. Zool Scr 15:21-31

Vrijenhoek RC, Schutz SJ, Gustafson RG, Lutz RA (1994) Cryptic species of deep-sea clams (Mollusca: Bivalvia: Vesicomyidae) from hydrothermal vent and cold-water seep environments. Deep Sea Res 41:1171-1189

Manuscript first received: January 13, 1995

Revised version accepted: October 24, 1995 